\title{
PROJECT-BASED LEARNING: A TEACHING APPROACH WHERE LEARNING COMES ALIVE \\ Besa Bytyqi
}

South East European University, North Macedonia

\begin{abstract}
"Doing projects" is a long-standing tradition in American education. According to Buck Institute for Education (BIE) (www.pblworks.org) the roots of PBL lie in this tradition. But the emergence of a method of teaching and learning called Project Based Learning (PBL) is the result of two important developments over the last 25 years. First, there has been a revolution in learning theory. Research in neuroscience and psychology has extended cognitive and behavioral models of learning-which support traditional direct instruction - to show that knowledge, thinking, doing, and the contexts for learning are inextricably tied. We now know that learning is partly a social activity; it takes place within the context of culture, community, and past experiences.

There is no unique accepted definition of PBL. However, BIE defines standards-focused PBL as a systematic teaching method that engages students in learning knowledge and skills through an extended inquiry process structured around complex, authentic questions and carefully designed products and tasks. This definition encompasses a spectrum ranging from brief projects of one to two weeks based on a single subject in one classroom to yearlong, interdisciplinary projects that involve community participation and adults outside the school. More important than the definitions are the attributes of effective projects. The BIE planning model is based on a number of criteria that distinguish carefully planned projects from other extended activities in the classroom.

Firstly, the model for PBL emerged from a number of medical schools especially the Case Western Reserve University in the United States of America in the 1950s and McMaster University Faculty of Health Sciences in Canada in the late 1960s (Boud and Feletti, 1997). The concern at that time was on the effectiveness of traditional science courses in preparing students for the real world and problems they would have to solve as physicians.

Markham (2009) describes that PBL integrates knowing and doing. Students learn knowledge and elements of the core curriculum, but also apply what they know to solve authentic problems and produce results that matter, so, the core of this methodology is learning by doing.

Generally, PBL in ESP courses enables students to develop and improve their language fluency and accuracy, writing skills while building personal qualities and skills such as self-confidence, problem solving, decision-making, and collaboration. (Fried-Booth, 2002; Stoller, 2006; Beckett and Slater, 2005)

Since PBL shifts the emphasis on learning activity from teachers to students, it can also help students become more autonomous learners who will transfer the skills they learned in the classroom to their lives outside of the classroom (James, 2006).

PBL affords flexibility for teachers in curriculum design and allows teachers to target material that motivates students (Tomei, Glick, \& Holst, 1999). PBL allows the learner to
\end{abstract}


be at the center of the process and promotes autonomy, problem solving, critical thinking, as well as interpersonal and life skills. Thomas (2000) proposed a definition of PBL from PBL handbooks as being "a teaching model that organizes learning around projects" and projects as being complex tasks based on challenging questions or problems that involve students in design, problem-solving, decision-making, and/or investigative activities, that give students opportunities to work relatively autonomously over extended periods of time, and culminate in realistic products or presentations (Jones, Rasmussen, \& Moffitt, 1997; Thomas, Mergendoller, \& Michaelson, 1999).

Some previous studies that investigate the implementation of PBL have shown its benefits for both teaching and learning process. Ichsan (2016) found that PBL was applicable and effective for teaching speaking. In addition, Simpson (2011) found that PBL helps the instructor to give task that is systematically based on the specific needs of the students. Apart from this, PBL also supports and enhances teamwork, higher-order thinking skills, presentation skills and self-confidence in the language.

Simpson (2011) proposes the following four stages of implementation of PBL:

\section{Starting the project}

This stage consists of several set of introduction of the teacher related to the project that needed to fulfill by the students. The students may select the topic of interest and relevancy. The teacher can create guiding questions so that students have idea about what to do and are encouraged to study or develop. Students then establish the project outline and plan the method of research, final outcomes and individual participation in the project.

\section{Developing the project}

This stage involves research, which is undertaken by all group members either individually, in pairs, or as a group. In this stage the instructor helps the students with the sources and the topic.

\section{Reporting to the class}

This step consists of presenting the project and receiving feedback about the project (what has been done so far). This stage requires teamwork, active listening and constructive feedback.

4. Assessing the project

In this final stage, students present their work orally. Students present their projects after which other students ask questions and comment. The final assessment is done by the teacher.

In conclusion, Project Based Learning is a teaching method in which students work on a project over an extended period of time (from a week up to a semester) that engages them in solving a real-world problem or answering a complex question. They demonstrate their knowledge and skills by creating a public product or presentation for a real audience. As a result, students develop deep content knowledge as well as critical thinking, collaboration, creativity, and communication skills. 


\section{REFERENCES}

Beckett, G.H. \& Slater, T. (2005). The project framework: a tool for language, content, and skills integration. ELT Journal. 59(2): 108-116. Oxford University Press.

Belcher, D. (2009). What ESP Is and Can Be: An Introduction. In D. Belcher (Ed.), English for Specific Purposes in Theory and Practice. Ann Arbor: University ofMichigan Press.

Boud, D., and Feletti, G. I. 1997. The Challenge of Problem-Based Learning. London:Kogan Page.

Fried-Booth, Diana L. (2002). Project Work. (2nd ed.). New York: Oxford University Press.

Ichsan, M. H. (2016) media.neliti.com Retrieved Aug 28, 2021 from https://media.neliti.com/ media/publications/213975-none.pdf

James, M. A. 2006. Teaching for Transfer in ELT. ELT Journal, Vol. 60 No. 2, 151-159. Oxford University Press.

Jones, B. F., Rasmussen, C. M., \& Moffitt, M. C. (1997). Real-life problem solving: A collaborative approach to interdisciplinary learning. Washington DC: American

Psychological Association. doi:10.1037/10266-000

Markham, T., Larmer, J., \& Ravitz, J. (2009). Project based learning handbook: A guide to standards-focused project based learning. Novato, CA: Buck Institute for Education.

Simpson, J (2011) Integrating PBL in an English Language Tourism Classroom in a Thai University. Australian Catholic University: Unpublished Dissertation

Stoller, F. (2006). Establishing a theoretical foundation for project-based learning in second and foreign-language contexts. In G.H. Beckett \& P.C. Miller (Eds.), Projectbased second and foreign language education: past, present, and future (pp.19-40). Greenwich, Connecticut: Information Age Publishing.

Thomas, J. W. (2000). A review of research on project-based learning. Retrieved from http://www.bie.org/images/uploads/general/9d06758fd346969cb63653d00dca55c0.Pdf

Thomas, J. W., Mergendoller, J. R., \& Michaelson, A. (1999). Project-based learning: A handbook for middle and high school teachers. Novato, CA: The Buck Institute for Education.

Tomei, J., Glick, C., \& Holst, M. (1999). Project work in the Japanese university classroom. The Language Teacher, 23(3), 5-8.

https://www.pblworks.org/what-is-pbl 